\title{
GURU DAN PROFESIONALITAS DALAM PENDIDIKAN
}

\author{
Parid Wajdi Almujtaba \\ Email:2010111210011@mhs.ulm.ac.id \\ Program Studi Pendidikan Sejarah Fakultas Keguruan dan Ilmu Pendidikan \\ Universitas Lambung Mangkurat \\ Banjarmasin
}

\begin{abstract}
Abstrak
Profesi guru merupakan profesi yang menuntut persyaratan khusus bagi calon tenaga pendidik atau guru di sekolah. Hal ini tercantum dalam Undang-undang yang menyatakan bahwa guru harus memiliki kualifikasi akademik S1 atau setara D.IV dan sertifikat pendidik. Disamping itu, guru juga dituntut harus memiliki kompetensi Pedagogik, Kepribadian, Sosial, dan Profesional. Undang-undang Nomor 14 Tahun 2005 tentang Guru dan Dosen disebutkan bahwa guru adalah pendidik profesional dengan tugas utama mendidik, mengajar, membimbing, mengarahkan, melatih, menilai, dan mengevaluasi peserta didik. Oleh karena itu, menjadi seorang guru bukan pekerjaan yang mudah. Selain guru memiliki tanggung jawab transfer of knowledge tetapi juga harus bisa melakukan transfer of value. Seorang guru juga harus bisa memahami bagaimana sebuah profesionalitas dalam lingkungan pendidikan. Dan seorang guru harus mampu mengetahui seperti apa cara untuk menjadikan seornag guru yang profesional
\end{abstract}

\section{PENDAHULUAN}

A. Konsep Profesi

Kata profesi dalam bahasa Inggris adalah "profession", dalam bahasa Belanda "professie" yang merupakan kata yang berasal dari bahasa Latin "professio" yang bermakna pengakuan atau pernyataan. Kata profesi juga terkait secara generik dengan kata "okupasi” (Indonesia), accupation (Inggris), accupatio (Latin) yang bermakna kesibukan atau kegiatan atau pekerjaan atau mata pencaharian.(Ananda, 2018: 1). 
Dalam Kamus Besar Bahasa Indonesia dinyatakan profesi adalah bidang pekerjaan yang dilandasi pendidikan keahlian (ketrampilan, kejuruan dan sebagainya) tertentu. Menurut Tilaar (2002:86) profesi merupakan pekerjaan, dapat juga berwujud sebagai jabatan di dalam suatu hirarki birokrasi yang menuntut keahlian tertentu serta memiliki etika khusus untuk jabatan tersebut serta pelayanan baku terhadap masyarakat. Hal senada dipaparkan Nata (2003:138) bahwa profesi adalah pernyataan atau pengakuan tentang bidang pekerjaan atau bidang pengabdian yang dipilih.( Ananda, 2018: 1).

Vollmer dan Mills sebagaimana dikutip Danim (2010:56) menyatakan profesi adalah suatu pekerjaan yang menuntut kemampuan intelektual khusus yang diperoleh melalui kegiatan belajarr dan pelatihan yang bertujuan untuk menguasai keterampilan atau keahlian dalam melayani atau memberikan advis kepada orang lain dengan memperoleh upah atau gaji dalam jumlah tertentu. Menurut Mudlofir (2014:17) profesi adalah suatu jabatan atau pekerjaan yang menuntut keahlian (expertise) dari para anggotanya, artinya, profesi tidak bisa dilakukan oleh sembarang orang yang tidak dilatih dan tidak disiapkan secara khusus untuk melakukan pekerjaan itu. Keahlian diperoleh melalui apa yang disebut profesionalisasi yang dilakukan sebelum seorang menjalani profesi itu maupun setelah menjalani suatu profesi. ( Ananda, 2018: 1-2).

Menurut pengetian diatas profesi adalah sebuah pekerjaan yang mana dalam pekerjaan tersebut harus dituntut keahlian dalam bidangnya, perlunya pendidikan, kemampuan dasar,dan juga keterampilan didalamnya. Sebuah profesi dapat bergerak didalam lingkungan hirarki dan birokrasi, namun dapat juga berupa layanan dan pengabdian terhadap masyarakat. Perlunya intelektual khusus dalam profesi yang didapat dari belajar dan pelatihan adalah bertujuan untuk menguasai bidang tersebut. Dikatakan juga bahwasanya sebuah profesi tidak dapat dilakukan oleh sembarang orang yang tidak disiapkan secara khusus untuk melakukan pekerjaan tersebut.

B. Konsep Profesi Guru 
Kata "GURU" terkadang ditengah-tengah masyarakat merupakan akronim dari orang yang di "gugu" dan di "tiru" yaitu orang yang selalu dapat ditaati dan diikuti (Yamin dan Maisah, 2010:88). Dalam hal ini guru adalah orang yang memberikan ilmu pengetahuan kepada orang lain yang melaksanakan pendidikan dan pembelajaran ditempat-tempat tertentu, tidak mesti di lembaga pendidikan formal, tetapi bisa juga di masjid, di rumah dan sebagainya (Djamarah, 2005:31)

Saat ini terjadi perluasan makna guru dari hanya sekedar penyampai ilmu pengetahuan kepada hal-hal yang lebih manusiawi sebagaimana dijelaskan Uno yang dikutip Aditya dan Wulandari (2011:28) bahwa guru adalah orang dewasa yang secara sadar bertanggung jawab dalam mendidik, mengajar dan membimbing peserta didik. Oleh karena itu guru memiliki peran kunci dalam peningkatan mutu pendidikan dan mereka berada di titik sentral dari setiap usaha reformasi pendidikan yang diarahkan pada perubahan-perubahan kualitatif. (Ananda, 2018: 1-2).

Profesi guru adalah profesi yang mana mengharuskan sebuah keahlian dalam bidang pendidikan, jadi semua prosesnya melalui jalur pendidikan dan didapat melalui pelatihan dilingkungan pendidikan. Profesi guru memerlukan keahlian khusus sebagai seorang guru, profesi guru ini sesuai dengan konsep profesi yang mana tidak boleh dilakukan oleh sembarang orang, harus dilakukan oleh orang yang menempuh jalur pendidikan dan terampil dibidang pendidikan tersebut.

\section{PERAN GURU SEBAGAI SEBUAH PROFESI}

A. Guru Sebagai Sebuah Profesi

Guru merupakan suatu profesi, yang berarti suatu jabatan yang memerlukan keahlian khusus sebagai guru dan tidak dapat dilakukan oleh sembarang orang diluar bidang pendidikan. Walaupun pada kenyataannya masih terdapat guru yang tidak memiliki latar belakang pendidikan bidang keguruan. Seorang guru berkaitan dengan aktivitas profesinya diharuskan mengetahui dan dapat menerapkan beberapa prinsip mengajar agar ia dapat melaksanakan tugasnya secara professional. (Susanto, 2020: 17). 
Para ahli pendidikan pada umumnya memasukkan jabatan guru sebagai pekerjaan profesional, yaitu pekerjaan yang hanya dapat dilakukan oleh mereka yang khusus dipersiapkan untuk itu dan bukan pekerjaan yang dilakukan oleh mereka yang karena tidak dapat memperoleh pekerjaan lain. Sebagaimana telah dikemukakan terdahulu berdasarkan persyaratan umum, jabatan guru memenuhi kriteria yang dikemukakan, oleh karena itu jabatan guru digolongkan kepada jabatan profesional. Dimana kekhususan jabatan guru dari jabatan profesional lainnya, dapat di simak dari kompetensi keguruan itu. (Wau, 2016: 9)

Guru adalah sebuah profesi. Kenapa, karena dapat dikatakan konsep profesi seperti yang telah dipaparkan diatas mencakup semua yang ada di seorang guru, guru adalah sebuah profesi yang bergerak dibidang pelayanan terhadap masyarakat .Seorang guru dituntut unuk menjadi seorang yang berpendidikan, makanya proses untuk mendapat sebuah gelar guru ditempuh melalui jalan yang khusus, seorang guru harus berproses dengan jalur yang berada dibidang pendidikan, melalui pelatihan khusus dan adanya keterampilan dibidang pendidikanlah yang menjadikan seorang guru dapat disebut sebuah profesi

\section{B. Peran, Hak, dan Kewajiban Guru}

Guru merupakan satu di antara profesi di bidang pendidikan. Dalam Undang-Undang No. 14 Tahun 2005, dikatakan guru adalah pendidik profesional dengan tugas utama mendidik, mengajar, membimbing, mengarahkan, melatih, menilai, dan mengevaluasi peserta didik pada pendidikan anak usia dini jalur pendidikan formal, pendidikan dasar, dan pendidikan menengah. Guru dapat diartikan sebagai orang yang tugasnya terkait dengan upaya mencerdaskan Profesi Keguruan 31 kehidupan bangsa dalam semua aspeknya, baik spiritual dan emosional, intelektual, fisikal, maupun aspek lainnya. (Susanto, 2020: 37).

Berdasarkan UU RI No.14 tahun 2005 tentang Guru dan Dosen Pasal 1, Guru adalah pendidik profesional dengan tugas utama mendidik, mengajar, 
membimbing, mengarahkan, melatih, menilai, dan mengevaluasi peserta didik pada pendidikan anak usia dini jalur pendidikan formal, pendidikan dasar, dan pendidikan menengah. Dosen adalah pendidik profesional dan ilmuan dengan tugas utama mentransformasikan, mengembangkan, dan menyebarluaskan ilmu pengetahuan, teknologi, dan seni melalui pendidikan, penelitian, dan pengabdian kepada masyarakat. (Susanto, 2020: 16).

Adams dan Dickey sebagaimana dikutip Hamalik (2004:123) yaitu peran guru sesungguhnya sangat luas yang meliputi empat hal besar yaitu:

1. Guru sebagai pengajar (teacher as instructor).

2. Guru sebagai pembimbing (teacher as counsellor)

3. Guru sebagai ilmuwan (teacher as scientist).

4. Guru sebagai sebagai pribadi (teacher as person).

Katz sebagaimana dikutip Sardiman (2003) memaparkan peran dan fungsi guru sebagai komunikator, sahabat yang dapat memberikan nasehat-nasehat, motivator sebagai pemberi inspirasi dorongan, pembimbing dalam pengembangan sikap dan tingkah laku serta nilai-nilai dan orang yang menguasa bahan yang diajarkan. Selanjutnya menurut Slameto (1995:97) peran dan fungsi guru sebagai berikut:

1. Mendidik dengan titik berat memberikan arah dan motivasi pencapaian tujuan baik jangka pendek maupun jangka panjang.

2. Memberi fasilitas pencapaian tujuan melalui pengalaman belajar yang memadai.

3. Membantu perkembangan aspek-aspek pribadi seperti sikap, nilai-nilai dan penyesuaian diri siswa.

\section{(Ananda, 2018: 22)}

Peran adalah suatu jabatan atau posisi seseorang dalam mejalankan suatu tugas atau aktivitas tertentu dalam suatu bidang pekerjaan. Dalam konteks pendidikan secara luas guru memiliki peran yang banyak dan luas, 
serta sangat penting, yaitu sebagai pelakasana dan ujung tombak pendidikan bagi peserta didik secara utuh dan menyeluruh untuk mencapai tujuan pendidikan. Oleh akrena itu tidak semua orang boleh menjadi guru. Yang boleh menjadi guru adalah hanya mereka yang memiliki kompetensi keahlian tertentu dan memenuhi persyatan yang telah ditentukan dalam peraturan perundang-undangan. Syarat tersebut antara lain berpendidikan minimal sarjana (S-1) atau diploma empat (D-IV) dan bersertifikat pendidik. Di samping itu harus sehat, baik jasmani maupun rohani yang diperlukan untuk mewujudkan tujuan pendidikan nasional. Ada pun tujuan pendidikan Indonesia sebagaimana tertuang dalam Undang-undang Sistem Pendidikan Nasional adalah: berkembangnya potensi peserta didik agar menjadi manusia yang beriman dan bertakwa kepada Tuhan Yang Maha Esa, berakhlak mulia, sehat, berilmu, cakap, kreatif, mandiri, dan menjadi warga negara yang demokratis serta bertanggung jawab. (Nurzaman\&tim

\section{,2019: 75)}

Adapun tugas guru adalah melaksanakan aktivitas berkaitan dengan pelaksanaan keseluruhan peran profesional sebagai guru. Sebagai contoh; peran guru sebagai pengajar, maka tugasnya adalah mengajar. Peran guru sebagai perencana pembelajaran, maka tugasnya adalah membuat perencanaan pembelajaran. Peran guru sebagai penilai (evaluator), maka tugasnya adalah melaksanakan penilaian, dst. Dengan kata lain, peran itu berkaitan dengan jabatan atau posisi, sedangkan tugas berkaitan dengan uraian pekerjaan atau aktivitas dalam melaksanakan peran yang dimiliki oleh seseorang. (Nurzaman\&tim,2019: 75)

Dalam menjalankan tugas dan profesinya, guru memiliki hak dan kewajiban yang harus dilaksanakan dan diperhatikan. Hak guru berarti suatu yang harus didapatkan olehnya setelah ia melaksanakan sejumlah kewajibannya sebagai guru. Kewajiban guru adalah sesuatu yang harus patut dilaksanakan oleh guru dalam menjalankan profesinya. Hak dan kewajiban guru sebagai pendidik diatur di semua peraturan perundang-undangan yang berkaitan dengan pendidikan. Dalam UU No. 14 
Tahun 2005 tentang guru dan dosen pada bagian kedua mengenai hak dan kewajiban pada pasal 14, adapun hak yang dimiliki oleh seorang guru sebagai berikut:

a) Memperoleh penghasilan di atas kebutuhan hidup minimum dan jaminan kesejahteraan sosial.

b) Mendapatkan promosi dan penghargaan sesuai dengan tugas dan prestasi kerja.

c) Memperoleh perlindungan dalam melaksanakan tugas dan hak atas kekayaan intelektual.

d) Memperoleh kesempatan untuk meningkatkan kompetensi.

e) Memperoleh dan memanfaatkan sarana dan prasarana pembelajaran untuk menunjang kelancaran tugas keprofesionalan.

f) Memiliki kebebasan dalam memberikan penilaian dan ikut menentukan kelulusan, penghargaan, dan atau sanksi kepada peserta didik sesuai dengan kaidah pendidikan, kode etik guru, dan peraturan perundang-undangan.

g) Memperoleh rasa aman dan jaminan keselamatan dalam melaksanakan tugas.

h) Memiliki kebebasan untuk berserikat dalam organisasi profesi.

i) Memiliki kesempatan untuk berperan dalam penentuan kebijakan pendidikan.

j) Memperoleh kesempatan untuk mengembangkan dan meningkatkan kualifikasi akademik dan kompetensi.

k) Memperoleh pelatihan dan pengembangan profesi dalam bidangnya. (Susanto, 2020: 44).

Dalam melaksanakan tugas keprofesionalan dalam UU No. 14 tahun 2005 tentang guru dan dosen, pada pasal 20 maka guru berkewajiban sebagai berikut:

a) Merencanakan pembelajaran, melaksanakan proses pembelajaran yang bermutu, serta menilai dan mengevaluasi hasil pembelajaran. 
b) Mengembangkan dan meningkatkan kualifikasi akademik dan kompetensi secara berkelanjutan sejalan dengan perkembangan ilmu pengetahuan, teknologi dan seni.

c) Bertindak objektif dan tidak diskriminatif atas dasar pertimbangan jenis kelamin, agama, suku, ras, dan kondisi fisik tertentu, atau latar belakang keluarga, dan status sosial ekonomi peserta didik dalam pembelajaran

d) Menjunjung tinggi peraturan perundang undangan, hukum dan kode etik guru, serta nilai nilai agama dan etika.

e) Memelihara dan memupuk persatuan dan kesatuan bangsa.

(Susanto, 2020: 47).

\section{GURU INDONESIA DAN TANTANGAN PROFESIONALISME}

Guru dalam mendidik seharusnya tidak hanya mengutamakan pengetahuan atau perkembangan intelektual saja, tetapi juga harus memperhatikan perkembangan seluruh pribadi peserta didik, baik jasmani, rohani, sosial, maupun spiritual dan emosionalnya sesuai dengan hakikat pendidikan. Hal ini dimaksudkan agar peserta didik pada akhirnya dapat menjadi manusia yang mampu menghadapi tantangan tantangan dalam kehidupan sebagai manusia dewasa. (Fauzi,2018: 243)

Sebagai pribadi, guru merupakan perwujudan diri dengan seluruh keunikan karakteristik yang sesuai dengan posisinya sebagai pemangku profesi keguruan. Kepribadian merupakan landasan utama bagi perwujudan diri sebagai guru yang efektif baik dalam melaksanakan tugas profesionalnya di lingkungan pendidikan dan di lingkungan kehidupan lainnya. Hal ini mengandung makna bahwa seorang guru harus mampu mewujudkan pribadi yang efektif untuk dapat melaksanakan fungsi dan tanggung jawabnya sebagai guru. Untuk itu, ia harus mengenal dirinya sendiri dan mampu mengembangkannya ke arah terwujudnya pribadi yang sehat dan paripurna (fully functioning person). (Fauzi,2018: 150)

Komponen kompetensi apa yang harus dimiliki guru untuk dapat disebut sebagai guru professional? Untuk mencapai standar guru profesional diperlukan suatu sistem pendidikan guru yang dapat memberikan jaminan bahwa lulusannya memiliki kompetensi sebagaimana yang dipersyaratkan, yang secara garis besar dikemas dalam empat 
kompetensi utama, yaitu kompetensi pedagogik, kompetensi profesional, kompetensi sosial, dan kompetensi kepribadian. Keempat kompetensi tersebut sifatnya integratif, artinya semua kompetensi tersebut harus dimiliki secara utuh pada saat yang bersamaan.

\section{(Nurzaman\&tim,2019: 44)}

Kedudukan guru sebagai tenaga profesional bertujuan untuk melaksanakan sistem pendidikan nasional dan mewujudkan tujuan pendidikan nasional yaitu berkembangnya potensi peserta didik agar menjadi manusia yang beriman dan bertakwa kepada Tuhan Yang Maha Esa, berakhlak mulia, sehat, berilmu, cakap, kreatif, mandiri, serta menjadi warga Negara yang demokratis dan bertanggung jawab (Nurzaman\&tim,2019: 45).

\section{SIMPULAN}

Guru merupakan pendidik yang bertanggungjawab atas anak didiknya untuk mencapai tujuan pendidikan yang telah ditetapkan melalui proses mendidik yang memerlukan kesiapan secara matang dan terencana. Oleh karena itu, sangat penting guru harus mampu merencanakan, melaksanakan, membimbing, melatih, dan mengevaluasi pembelajaran yang disiapkan guru. Profesi merupakan suatu pekerjaan/jabatan yang menuntut suatu keahlian, memiliki persyaratan yang harus dipenuhi, kode etik, tanggung jawab yang diperoleh melalui pendidikan, latihan, pembinaan, dan pengalaman pada bidang tertentu.

Undang-Undang Guru dan Dosen No.14 tahun 2005 profesi keguruan adalah pendidikan profesional dengan tugas utama mendidik, mengajar, melatih, menilai dan mengevaluasi peserta didik pada usia dini, jalur pendidikan formal, pendidikan dasar dan pendidikan menengah

Profesionalisme memang menjadi hal yang kerap dituntut dan diharapkan dalam berbagai profesi, tak terkecuali guru. Di kalangan guru, istilah profesionalisme sering dihubungkan dengan program sertifikasi guru. Program pemerintah yang dilahirkan melalui UndangUndang Nomor 14 Tahun 2005 tentang Guru dan Dosen ini bertujuan untuk :

(1) menentukan kelayakan guru dalam melaksanakan tugas sebagai pendidik profesional,

(2) meningkatkan proses dan hasil pembelajaran,

(3) meningkatkan kesejahteraan guru, serta

(4) meningkatkan martabat guru dalam rangka mewujudkan pendidikan nasional bermutu 


\section{REFERENSI}

Efendi, I., Prawitasari, M., \& Susanto, H. (2021). Implementasi Penilaian Pembelajaran Pada Kurikulum 2013 Mata Pelajaran Sejarah. Prabayaksa: Journal of History Education, 1(1), 21-25.

Susanto, H. (2020). Profesi Keguruan. Banjarmasin: FKIP Universitas Lambung Mangkurat.

Susanto, H., \& Akmal, H. (2018). Efektivitas Penggunaan Aplikasi Pembelajaran Berbasis Mobile Smartphone Sebagai Media Pengenalan Sejarah Lokal Masa Revolusi Fisik Di Kalimantan Selatan Pada Siswa Sekolah Menengah Atas. HISTORIA: Jurnal Program Studi Pendidikan Sejarah, 6(2), 197-206.

Susanto, H., Irmawati, I., Akmal, H., \& Abbas, E. W. (2021). Media Film Dokumenter Masuknya Islam Ke Nusantara dan Pengaruhnya Terhadap Keterampilan Berpikir Kritis Siswa. HISTORIA: Jurnal Program Studi Pendidikan Sejarah, 9(1).

Syaharuddin, S., \& Susanto, H. (2019). Sejarah Pendidikan Indonesia (Era Pra Kolonialisme Nusantara sampai Reformasi). Banjarmasin: FKIP Universitas Lambung Mangkurat.

Ananda, R. (2018). Profesi Pendidik dan Tenaga Kependidikan (Telaah Tehadap Pendidik Dan Tenaga Kependidikan). Medan: Lembaga Peduli Pengembangan Pendidikan Indonesia (LPPPI)

Wau, Yasaratodo.dan Tim. (2016). “Profesi Kependidikan”. Medan: Tim Pengembang Bahan Bahan Ajar Profesi Kependidikan FIP - Unimed

AM, E. Nurzaman, A. Alinurdin, dan Palogo Balianto. (2019). "Profesi Keguruan." Tangerang Selatan: UNPAM PRESS

Fauzi,I (2018). "Etika Profesi Keguruan" ”.Jember, IAIN Jember Press 